\title{
Ultrasonographic Diagnosis of Unilateral Scrotal Hernia, Varicocele and Sperm Granuloma in a Ram
}

\author{
Delia Lacasta, Luís M. Ferrer, Juan J. Ramos, Pablo Gómez Ochoa \\ Departamento de Patología Animal Facultad de Veterinaria Zaragoza, Spain \\ Received December 28, 2008 \\ Accepted May 18, 2009
}

\begin{abstract}
A four-year-old ram was presented with a conspicuous hemilateral scrotal enlargement that was noticed four weeks before. Based on the history, clinical signs, palpation, trans-scrotal ultrasonography and semen collection, a left scrotal hernia was diagnosed. Ultrasonographic examination showed a presumably omental fat scrotal hernia with an atrophic left testis and varicocele, and the presence of two sperm cysts could be observed in the right epididymal tail. The testis appeared as a homogeneous and moderately echogenic structure and it was possible to distinguish atrophy of the left testis that was covered by a hyperechoic area, presumably omental fat, within the hernial sac. In addition, on ultrasound examination non-echogenic tortuous areas were present and diagnosed as varicocele. Post mortem examination confirmed gross lesions identified ultrasonographically. The libido of the ram was normal but the semen showed total azoospermia.

Ultrasound imaging can be used as a diagnostic technique to confirm the diagnosis of scrotal hernia, varicocele, sperm cyst and testis mineralization.
\end{abstract}

Sheep, reproduction, testicular pathology, ultrasonography

The use of diagnostic ultrasound equipment is even more widespread in various sectors of veterinary practice, as it is a non-invasive and innocuous technique aiding diagnosis. In genital disorders, ultrasonography permits the diagnosis of several types of scrotal, testicular and epididymal lesions in rams (Ahmad et al. 1991; Ahmad et al. 2000).

This communication reports the clinical, pathological, spermatologic and ultrasonographic features of a case of scrotal hernia and sperm cyst in a ram.

\section{Materials and Methods}

A four-year-old Salz ram was admitted to the Veterinary Faculty Hospital, University of Zaragoza, Spain, with a hemilateral scrotal enlargement that rendered him reproductively unsound.

The ram came from a Salz flock comprised of 700 ewes and 16 males in the east of Zaragoza, Spain. The Salz breed is a meat sheep developed by crossing 2 strains of Romanov rams with Rasa Aragonesa ewes. Rasa Aragonesa is the local breed (55-65 kg, females, and $75-85 \mathrm{~kg}$, males) characterized by its sturdiness and production of high-quality light lambs. The Romanov breed has good prolificacy with 3-4 lambs/birth. The Salz strain is considered fixed, containing equal proportions of Rasa Aragonesa and Romanov genes. The new breed is characterized by good sturdiness and better prolificacy than the local breed (Maria and Ascaso 1999).

Anamnesis demonstrated that the ram had had normal reproductive activity in recent years, but scrotal enlargement had been noticed four weeks earlier. There were no differences in libido before or after the lesion.

\section{Results and Discussion}

On examination at the Veterinary Faculty Hospital, the ram showed a good body condition (score 3.5) and normal clinical indicators (temperature: $39.1^{\circ} \mathrm{C}$; respiratory rate: $48 \mathrm{bpm}$; heart rate: $80 \mathrm{bpm}$. The only clinical sign was the hemilateral scrotal enlargement. Physical examination revealed that the left side of the scrotum was approximately four times larger than the right. Palpation of the scrotum failed to elicit signs of pain. The enlargement was resilient on palpation and it was possible to detect

Address for correspondence:

Dra. Delia Lacasta

Departamento de Patología Animal

Facultad de Veterinaria C/ Miguel Servet 177

50013-Zaragoza, Spain 
the small size of the left testis with a solid and cold mass in the upper scrotal side. The mass was not reducible but was diagnosed as a possible scrotal hernia. The right side of the scrotum was normal, and the right testis was movable within its tunic.

Trans-scrotal ultrasonography was performed with an ATL HDI 3500 machine using a wide range microconvex probe ( 5 to $8 \mathrm{MHz}$ ) and a high frequency (6 to $12 \mathrm{MHz}$ ) linear transducer. The testis appeared as a homogeneous and moderately echogenic structure, and it was possible to distinguish the atrophy of the left testis that was covered by a hyperechoic area, presumably omental fat, within the hernial sac (Plate XV, Fig. 1). In addition, on ultrasound examination, non-echogenic tortuous areas were present and diagnosed as varicocele (Plate XV, Fig. 2). On the ultrasound examination of the right scrotum, two seminal cysts were observed in the tail of the epididymis (Plate XVI, Fig. 3) and some points of testicular mineralisation (Plate XVI, Fig. 4).

Semen was collected using electrical stimulation. Spermatologic examination revealed total azoospermia.

Due to poor prognosis, the ram was slaughtered. A humane sacrifice was carried out with pentobarbital sodium $200 \mathrm{mg}$ (Dolethal ${ }^{\circledR}, 0.7 \mathrm{ml} / \mathrm{kg}$, Vetoquinol), and necropsy was performed. On post mortem examination, scrotal hernia was confirmed. It contained exclusively omental fat, showing adherences that made it impossible to reduce the hernia. Muscular hypertrophy of the tunica dartos was observed and the left testis appeared completely atrophied with only the epididymis being apparent. The pampiniform plexus veins were dilated forming a varicocele, confirming the ultrasonografic diagnosis. The right testis appeared normal but after a longitudinal section of the testis, seminal cysts were observed on the tail of the right epididymis.

In young lambs, the scrotal hernia is probably inherited as a recessive character, as in other domestic animal species (Roberts 1988). However, in adult rams, the cause of the hemilateral hernia is thought to be trauma (Braun and Cole 1985), especially in group-housed rams. Another possible influence on acquired scrotal hernia is the hormone concentration at the approach of the breeding season. The atrophic left testis and the varicocele might be the consequence of omental fat pressure.

It was concluded that ultrasound imaging could be used as a diagnostic technique to confirm the diagnosis of scrotal hernia, varicocele, sperm cyst and testis mineralization. To the authors' knowledge, ultrasonographic diagnosis of varicocele had not been described in the literature before.

\section{Ultrasonografická diagnostika jednostranné skrotální hernie, varikokély a spermatického granulomu u čtyřletého berana}

Závažné hemilaterální zduření v oblasti šourku trvající čtyři týdny bylo pozorováno u čtyřletého berana. Z informací získaných z anamnézy, klinického vyšetření, palpací, trans-skrotální ultrasonografií a z odběru semene, byla diagnostikována levá šourková kýla. Ultrasonografickým vyšetřením byla v kýlním vaku zjištěna předpokládaná prrítomnost omentálního tuku s atrofickým levým varletem a varikokélou, a zároveň byly zjištěny dvě cysty v cauda epididymis pravého nadvarlete. Tkáň varlete se ultrasonograficky jevila jako homogenní, mírně echogenní struktura, takže bylo možné odlišit oblast atrofovaného levého varlete, která se jevila hyperechogenní. Tato hyperechogenita byla způsobena předpokládanou př́tomností omentálního tuku uvnitř kýlního vaku, který pokrýval atrofickou tkáň varlete. Současně byla ultrazvukem zjištěná přítomnost klikatých hypoechogenních linií, ukazující na prrítomnost varikokély. Provedené pato-morfologické vyšetření potvrdilo těžká poranění, jež byla identifikována ultrasonograficky. Libido berana bylo nezměněné, ale ejakulát vykazoval celkovou azoospermii.

Ultrazvukové zobrazovací metody mohou být využity jako vhodná diagnostická tech- 
nika k potvrzení diagnózy skrotální hernie, varikokély, nadvarletních cyst a mineralizace varlete.

\section{References}

Ahmad N, Noakes DE, Subandrio AL 1991: B-mode real time ultrasonographic imaging of the testis and epididymis of sheep and goats. Vet Rec 128: 491-496

Ahmad N, England GC, Noakes DE 2000: Ultrasonography of spontaneous lesions of the genital system of three rams, and their influence on semen quality. Vet Rec 146:10-15

Braun WF, Cole WJ 1985: Unilateral scrotal hernia repair in a ram lamb. J Am Vet Med Assoc 187: 500

María GA, Ascaso MS 1999: Litter size, lambing interval and lamb mortality of Salz, Rasa Aragonesa, Romanov and F1 ewes on accelerated lambing management. Small Rum Res 32: 167-172

Roberts SJ 1988: Scrotal hernia in rams. A case report. Cornell Vet 78: 351-352 

Plate XV

Lacasta D. et al.: Ultrasonographic ... pp. 657-659

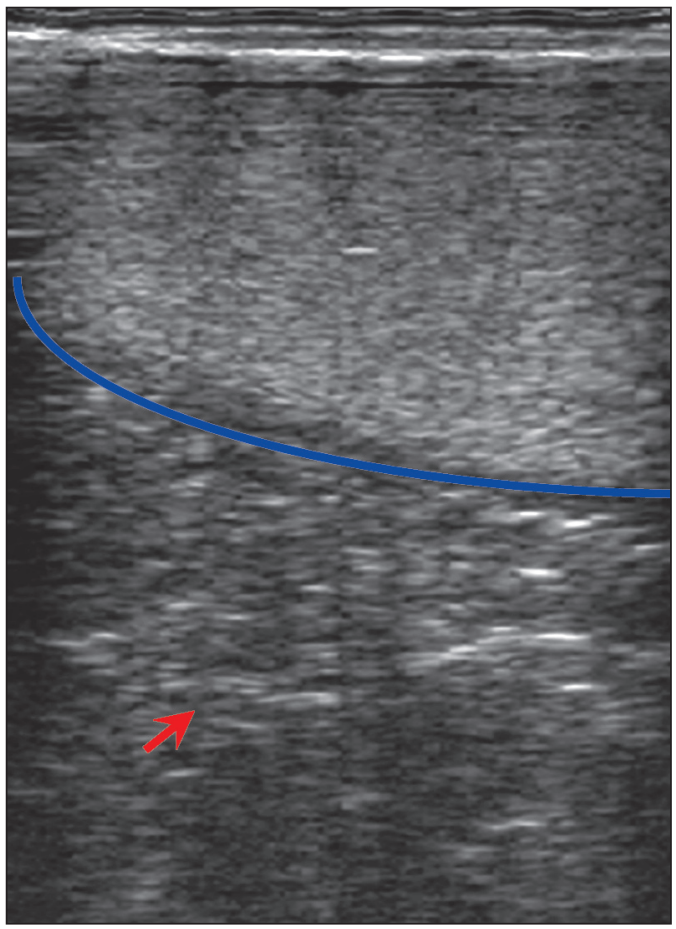

Fig. 1. Omental fat scrotal hernia

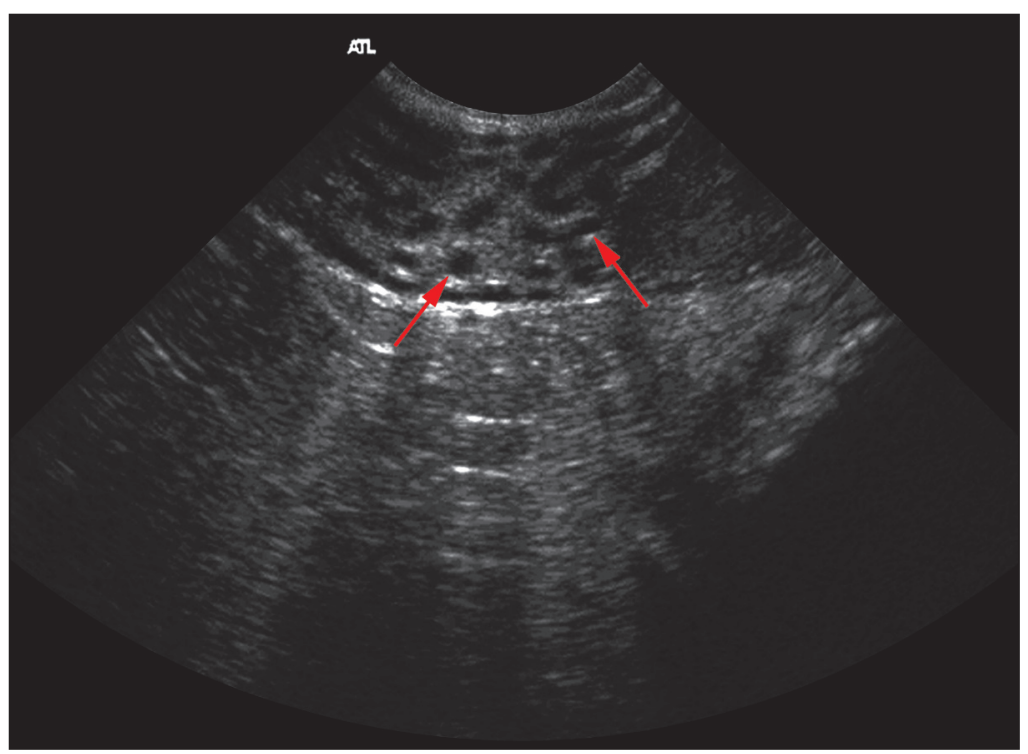

Fig. 2. Non-ecogenic tortuous areas corresponding to a variocele 


\section{Plate XVI}

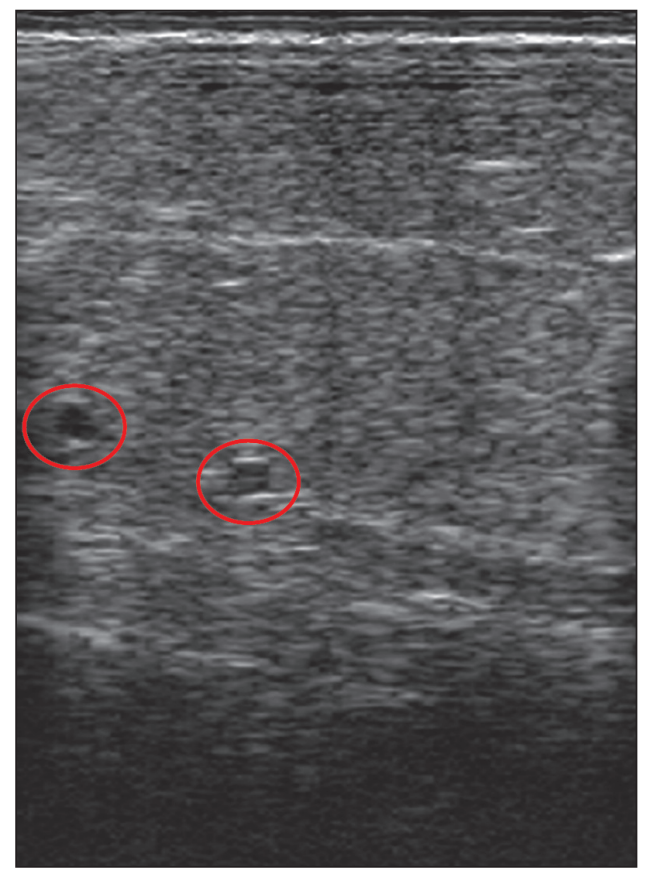

Fig. 3. Spermatic cycsts in the right epididymal tail

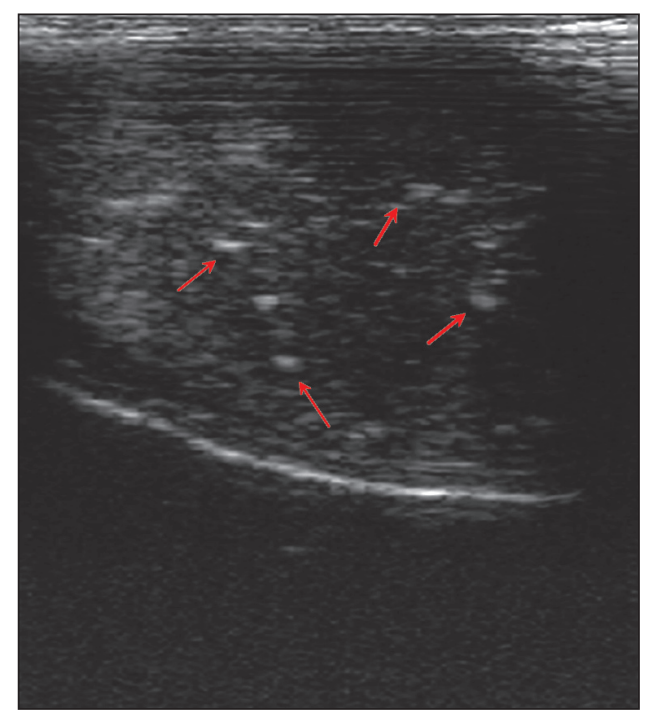

Fig. 4. Mineralisation in the right testis 